\title{
EXPERIMENTAL ASSESSMENT OF BIOLOGICAL POTENTIAL OF COLLAGEN MEMBRANES IN RECONSTRUCTION OF FULL-THICKNESS HYALINE CARTILAGE DEFECTS
}

Lazishvili GD ${ }^{1} \otimes$, Egiazaryan $\mathrm{KA}^{1}$, Nikishin $\mathrm{DV}^{2}$, Voroncov $\mathrm{AA}^{3}$, Klinov DV ${ }^{4}$

Pirogov Russian National Research Medical University, Moscow, Russia

2 OOO Aptos Group, Moscow, Russia

${ }^{3}$ Doctor Vorontsov's Veterinary Center for Surgery and Oncology, Moscow, Russia

${ }^{4}$ Federal Research and Clinical Center of Physical-Chemical Medicine under the Federal Medical Biological Agency, Moscow, Russia

Investigation of the efficacy of collagen membranes used in the full-thickness hyaline cartilage defect surgery is extremely urgent from the point of view of everyday healthcare. However, there is no information about the collagen membrane transformation timeframe, patterns and type of tissue the membrane transforms into, nor on the quality of the newly formed cartilage, which hinders the use of collagen membranes in clinical practice. This study aimed to investigate the biological potential of collagen membranes and their capacity to transform into cartilage tissue. The study involved four pigs as subjects. We induced a full-thickness cartilage defect on their right hind limb joint and implanted an Ortokeep collagen membrane to remedy it. Two full-thickness cartilage defects were induced on the left hind limb joints of the animals, one was treated with an implanted Chondro-Gide collagen membrane, the other remained without a membrane. The animals were withdrawn from the experiment at 2, 3, 4, 6 months after the operation. This report contains results of the macroscopic and microscopic analyses revealing the character of cartilage tissue regeneration at various timepoints post-surgery. The collagen membranes proved to have a high biological potential and a capacity to transform into cartilage tissue. The cartilages were identifiable from the $3^{\text {rd }}$ month of the study. Their thickness was growing significantly $(p<0.05)$ up to the 4 th month post-surgery, gaining $18.7 \%$ in group 1 and $12.8 \%$ in group 2; afterwards, the formed tissue "matured". We have shown that the AMIC technique allows significant $(p<0.05)$ reduction of the bone tissue destruction area.

Keywords: cartilage, local defect, knee joint, AMIC technology, osteochondral defect, collagen membrane, mosaicplasty

Author contribution: Lazishvili GD — design of the experiment, participation in the experimental surgery, analysis of literature and experimental materials, article authoring; Yeghiazaryan KA — analysis of literature, experimental results; Nikishin DV — processing and analysis of the experimental data, article authoring; Vorontsov AA - execution of the experimental surgery; Klinov DV - Ortokeep collagen membrane design and development.

Compliance with ethical standards: the study was approved by the Ethics Committee of the Center for Preclinical Research of Penza (Minutes № 1-19 of March 11, 2019). The animals were kept and used in compliance with the ethical standards and International requirements for humane treatment of laboratory (experimental) animals, as well as GOST R ISO 10993-1-2009 Medical Devices.

$\bowtie$ Correspondence should be addressed: Guram D. Lazishvili

Ostrovityanova, 1, 117997, Moscow; guramlaz@gmail.com

Received: 19.07.2021 Accepted: 05.08.2021 Published online: 20.08.2021

DOI: $10.24075 /$ brsmu.2021.038

\section{ЭКСПЕРИМЕНТАЛЬНАЯ ОЦЕНКА БИОЛОГИЧЕСКОГО ПОТЕНЦИАЛА КОЛЛАГЕНОВЫХ МЕМБРАН ПРИ РЕКОНСТРУКЦИИ ПОЛНОСЛОЙНЫХ ДЕФЕКТОВ ГИАЛИНОВОГО ХРЯЩА}

Г. Д. Лазишвили ${ }^{\otimes}$, К. А. Егиазарян ${ }^{1}$, Д. В. Никишин ${ }^{2}$, А. А. Воронцов ${ }^{3}$, Д. В. Клинов ${ }^{4}$

${ }^{1}$ Российский национальный исследовательский медицинский университет» имени Н. И. Пирогова, Москва, Россия

2 ООО «Аптос групп», Москва, Россия

${ }^{3}$ Клиника «Ветеринарный центр хирургии и онкологии доктора Воронцова», Москва, Россия

4 Федеральный научно-клинический центр физико-химической медицины Федерального медико-биологического агентства, Москва, Россия

Изучение эффективности применения коллагеновых мембран при хирургическом лечении полнослойных дефектов гиалинового хряща крайне актуально для практического здравоохранения. Отсутствие сведений о том, в какие сроки, как и в какую хрящевую ткань трансформируются коллагеновые мембраны, каково качество вновь образованного хряща, сдерживает их применение в клинической практике. Целью исследования было изучить биологический потенциал коллагеновых мембран и их способность к трансформации в хрящевую ткань. Исследование проводили на четырех свиньях. На суставах правых задних конечностей формировали полнослойный дефект хряща и имплантировали коллагеновую мембрану Оrtokeер. На суставах левых задних конечностей формировали по два полнослойных дефекта хряща. На один дефект имплантировали коллагеновю мембрану Сhondro-Gide, на второй десект мембрану не имплантировали. Животных выводили из эксперимента в сроки 2, 3, 4, 6 месяцев после операции. Представлены макроскопический и микроскопический анализ характера регенерации хрящевой ткани в различные сроки после операции. Результаты показали высокий биологический потенциал коллагеновых мембран и их возможность трансформироваться в хрящевую ткань. Хрящ выявлялся с 3-го месяца исследования. Отмечена тенденция к статистически достоверному ( $p<0,05)$ увеличению его толщины вплоть до 4-го месяца (в группе 1 - на 18,7\%, во группе 2 - на 12,8\%) с последующим его “созреванием». Показано, что при использовании технологии АМІС статистически достоверно (р < 0,05) уменьшается область деструкции костной ткани.

Ключевые слова: хрящ, локальный десект, коленный сустав, технология АМІС, костно-хрящевой десект, коллагеновая мембрана, мозаичная пластика

Вклад авторов: Г. Д. Лазишвили - дизайн эксперимента, участие в выполнении экспериментальных операций, анализ данных литературы и материалов эксперимента, написание статьи; К. А. Егиазарян - анализ данных литературы, результатов эксперимента; Д. В. Никишин - обработка и анализ данных эксперимента, участие в написании статьи; А. А. Воронцов - выполнение экспериментальных операций; Д. В. Клинов - автор и разработчик коллагеновой мембраны Ortokeep.

Соблюдение этических стандартов: исследование одобрено этическим комитетом Центра доклинических исследований г. Пенза (протокол № 1-19 от 11 марта 2019 г.). Содержание животных и манипуляции с ними соответствуют этическим нормам и Международным требованиям по гуманному отношению к лабораторным (экспериментальным) животным, а также ГОСТ Р ИСО 10993-1-2009 «Изделия медицинские».

Для корреспонденции: Гурам Давидович Лазишвили ул. Островитянова, д. 1, 117997, г. Москва; guramlaz@gmail.com

Статья получена: 19.07.2021 Статья принята к печати: 05.08.2021 Опубликована онлайн: 20.08.2021

DOI: $10.24075 /$ vrgmu.2021.038 
In the recent years, AMIC (autologous matrix induced chondrogenesis) has grown widely popular as a full-thickness hyaline cartilage defect restoration technique [1-4]. The method relies on holes made in the subchondral bone and allowing passage of bone marrow to the defect's surface, which delivers bone marrow stromal cells inducing regeneration. The resulting red bone marrow "superclot" is stabilized by a collagen membrane implanted in the cartilage defect area. The natural cell scaffolding protects and binds progenitor cells inside the "biological chamber", stimulating their differentiation and subsequent cartilage repair $[3,5]$

The benefits of AMIC are clear. It is a minimally invasive single step procedure that does not require chondrocyte culturing; it enables restoration of large cartilage defects $\left(\geq 6-8 \mathrm{~cm}^{2}\right)$; it is a simple surgical technique; its efficacy in relieving pain, restoring joint function and ensuring patient satisfaction with treatment outcomes has been proven.

Despite the wide popularity of AMIC, many controversial and unresolved issues remain. In particular, little is known about the time it takes the membrane to degrade, the nature of its transformation into cartilage tissue and the quality of cartilage tissue formed at the membrane implantation site [6, 7].

Currently, collagen membrane is the most demanded biological material used in cartilage tissue restorations. Unfortunately, the high cost of imported membranes disallows widespread introduction of AMIC into everyday clinical practice at domestic medical institutions. At the same time, cartilage restoration is one of the highly demanded operations. This fact determined the need to develop a domestic analogue that meets all the current requirements practitioners have for collagen membranes.

This study aimed to experimentally investigate the biological potential of collagen membranes and their capacity to transform into cartilage tissue.

\section{METHODS}

We used two types of collagen membranes, different in composition, structure and nature of production.
The main (tested) membrane was the Ortokeep membrane developed by Russian scientists (Ortosoft; Russia). It is formed by electrospinning from nanofibers (300-500 nm in diameter), which are a mixture of bovine type I collagen and polylactide. Both sides of the membrane have similar microrelief and wettability. By the formation method and structure of the nanofibers, Ortokeep is radically different from the foreign analogues, which allows an objective comparative analysis of their biological potential.

We selected a Chondro-Gide collagen membrane (Geistlich Pharma; Switzerland) as a control membrane for our experiments. Chondro-Gide is synthesized from pork collagen types I and III through natural resorption. This membrane is the most popular bioproduct, it is widely used to repair full-thickness cartilage defects, which is why we took it as a control membrane.

\section{Experiment model}

The experimental animals were four White Russian breed pigs, 6 months old, weighing 68/67.4/79/73 kg. They were kept in the subsidiary farm of the Center for Preclinical Research (Penza), isolated from the general livestock. At the beginning of the experiment, the animals were in a satisfactory condition, had a light color, independently took food and water, showed no external manifestations of a disease. Their records contained no entries describing diseases. All animals spent 3 weeks before the experiment in isolation, with their feeding dosed. The animals received individually calculated doses of systemic analgesics (xylazine, etc.) used in veterinary and clinical medicine. The depth of anesthesia was controlled by systemic reactions: spontaneous breathing, heart rate, blood pressure, state of the pupil, pulse oximetry. For respiratory support, we employed an anesthesia and respiratory device that delivered oxygen-air (anestetic gas) mixture of oxygen (75-85\%), air and 1.0-3.0 vol.\% of Isoflurane (aerran) in a semi-closed circuit.

On the right hind limb joints of each animal, using a round bur, we made one full-thickness cartilage defect (defect № 1) of rectangular shape, measuring $1 \times 0.5 \mathrm{~cm}$, reaching the subchondral bone (Fig. 1A). With a thin drill (diameter of $1.5 \mathrm{~mm}$ ),

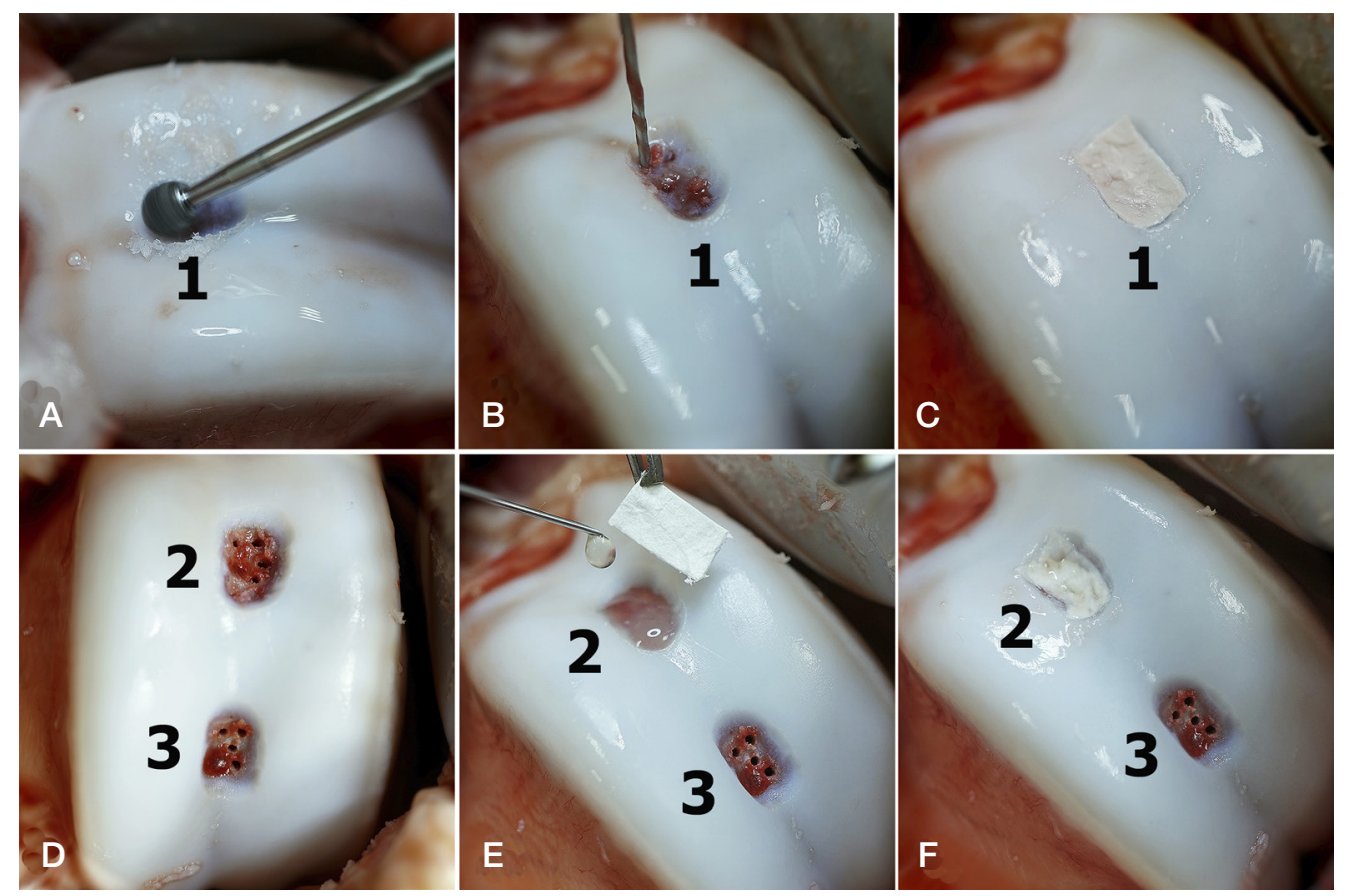

Fig. 1. Stages of formation of full-thickness defects and implantation of collagen membranes. 1 — defect № 1 (implantation of the Ortokeep membrane); 2 - defect № 2 (implantation of the Chondro-Gide membrane); 3 — defect № 3 (no membrane implantation) 


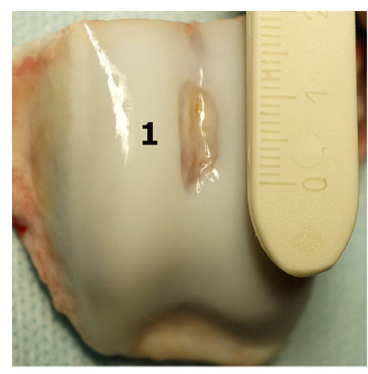

2 months

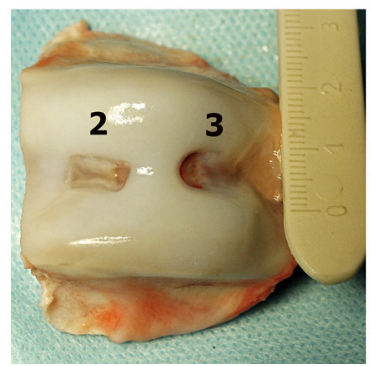

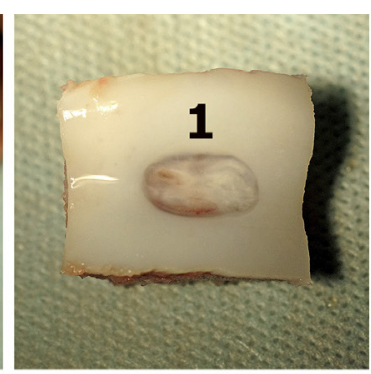

3 months

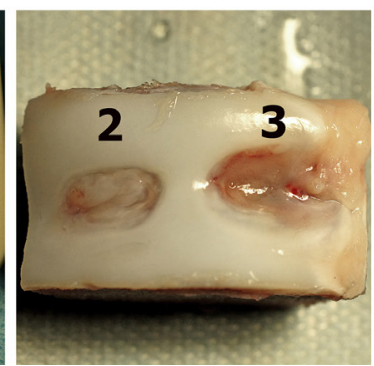

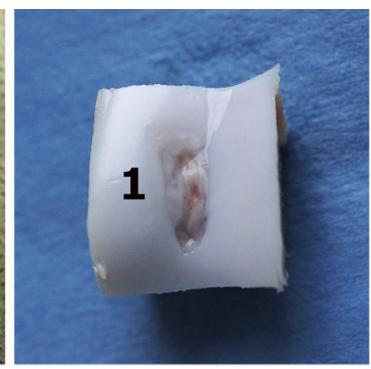

4 months

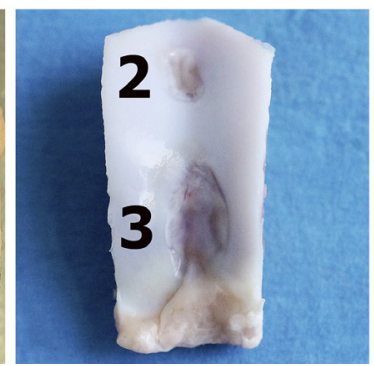

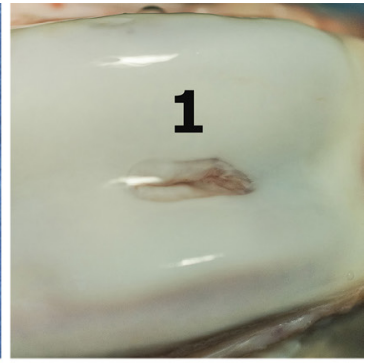

6 months

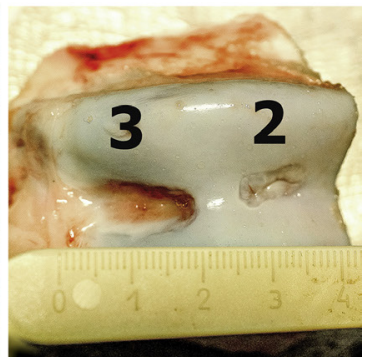

Fig. 2. Macro specimen at various timepoints post surgery. 1 - defect № 1 after implantation of the Ortokeep membrane; 2 - defect № 2 after implantation of the Chondro-Gide membrane; 3 - defect № 3, no membrane implantation

we reamed the subchondral bone to a depth of $1 \mathrm{~cm}$, thus letting bone marrow onto the surface of the defect (Fig. 1B). The Ortokeep collagen membrane was shaped appropriately for the defect and attached to the subchondral bone with fibrin glue (Fig. 1C).

On the left hind limb joints we made two defects, defect No. 2 to be covered with the Chondro Gide membrane and defect № 3 to remain as is for control purposes (Fig. 1D). The collagen membrane was modeled according to the shape and size of the defect. After reaming the subchondral bone, we applied fibrin glue to defect № 2 and implanted the Chondro-Gide collagen membrane (Fig. 1E). No membrane was implanted onto the control defect № 3 (Fig. 1F).

The animals were removed from the experiment 2, 3, 4, 6 months post-surgery by anesthesia (xylazine $15 \mathrm{ml}$, zoletil $1.5 \mathrm{ml}$ I.M.) followed by bloodletting (transection of the carotid arteries). For subsequent histological examination, we collected large bone-cartilage fragments containing the studied defects. For the purpose of microscopic examination, one biopsy fragment was taken from the central part of each defect.
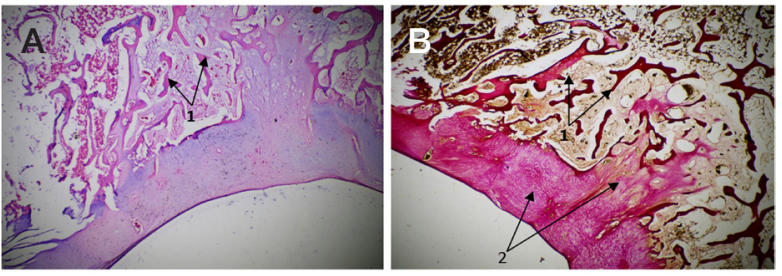

2 months

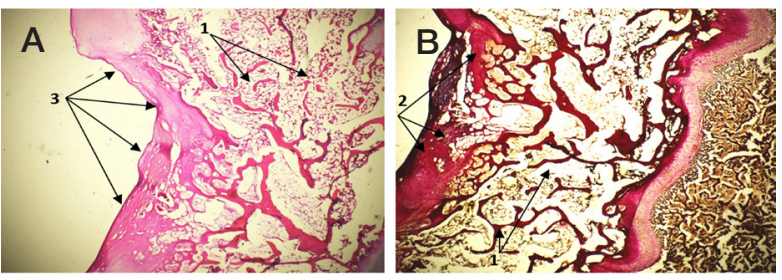

4 months
The bone-cartilage underwent gentle acid decalcification followed by the standard histological preparation. Histological sections 7-8 $\mu \mathrm{m}$ thick were stained with hematoxylin and eosin (Van Gieson's stain). Using a microscope with a digital 12-megapixel camera attachment (Sony; Japan) we took micrographs of at least 5 views of each histological section, studied the inflammatory response, structure of the tissues, their percentage ratio in the defect area, state of the microvasculature.

The obtained data were processed with the help of Statistica v.10 software packages (StatSoft; USA). The assessment of normality of distribution relied on the Shapiro-Wilk test. All the parameters described in this work had a distribution close to normal. For each parameter, we calculated the arithmetic mean (M) and the arithmetic mean error (m).

The significance of differences between groups was determined with the help of Fisher's exact test and nonparametric Kolmogorov-Smirnov test. The differences were considered significant at $95 \%$ probability threshold $(p<0.05)$.

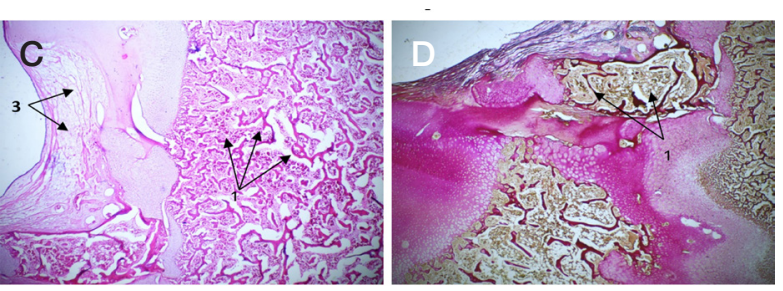

3 months

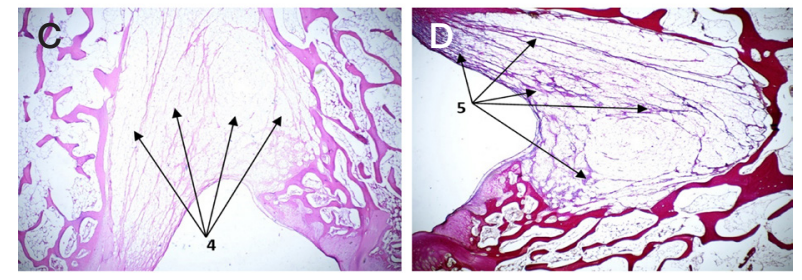

6 months

Fig. 3. Microscopic examination of defect № 3, control group; staining with hematoxylin and eosin, — 40 (A); Van Gieson's stain, $\times 40$ (B). 1 — osteodystrophy; 2 - coarse fibrous connective tissue; 3 - developing "crater" defect in cartilage and bone tissues; 4 — groups of adipocytes filling the "crater" defect; 5 - bundles of collagen fibers between islets of adipocytes 

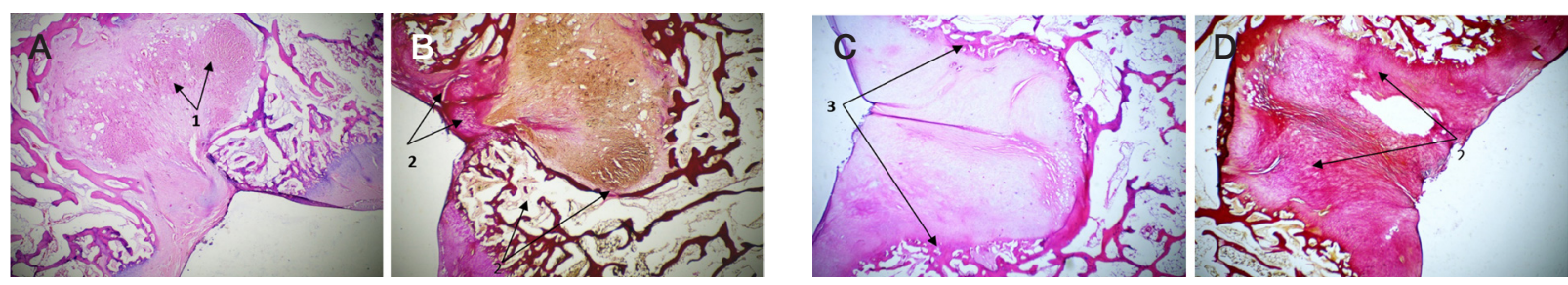

2 months

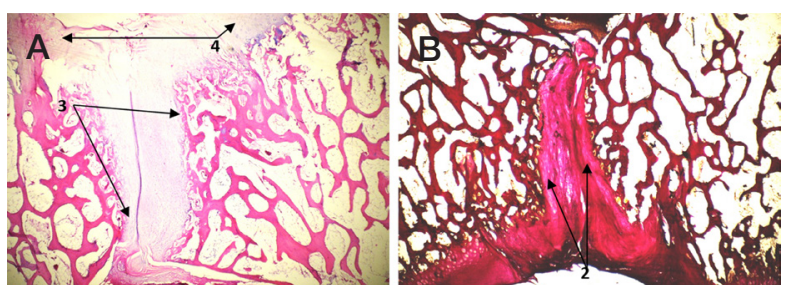

4 months

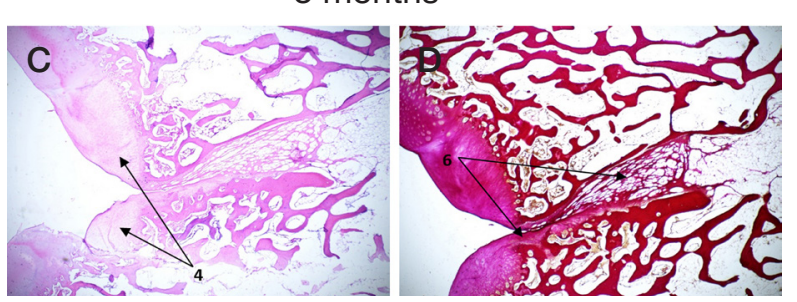

6 months

Fig. 4. Microscopic examination of defect № 1 after implantation of the Ortokeep membrane; staining with hematoxylin and eosin, $\times 40$ (A); Van Gieson's stain, $\times 40$ (B). 1 - fibrin; 2 - coarse fibrous connective tissue; 3 - developing cylindrical defect, active neoosteogenesis evident at the edges; 4 - neochondrogenesis; 5 - the defect shrunk sharply with formation of a slit cavity in the center

\section{RESULTS}

\section{Macroscopic examination}

Macroscopic examination of the control group samples (defect № 3, no membrane) revealed defect expansion without signs of cartilage tissue regeneration on its surface. The situation progressed into the 6th month post-surgery (Fig. 2).

At the same time, there was no pronounced expansion of the defects detected in the experimental groups (defects № 1 and № 2). The bed of the defects was even, but not uniform. Palpation revealed the bed to be elastic. Both defects were covered with a viable stable cartilage tissue (see Fig. 2).

\section{Microscopic examination}

Microscopic examination of the control group defect (defect № 3) revealed progression of the bone tissue destruction process and very weak signs of chondrogenesis, seen only in the immediate vicinity of the intact cartilage (Fig. 3).

Examination of the histological slides of samples with the Ortokeep membrane revealed no inflammatory process and
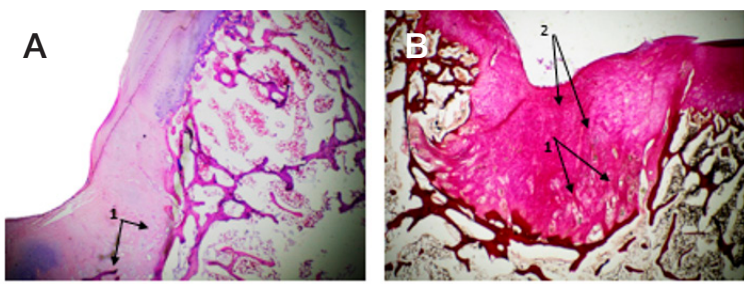

2 months
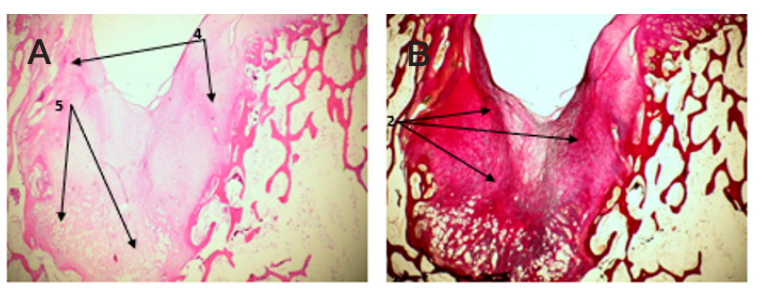

4 months leukocyte infiltration at all animal withdrawal timepoints. Up to the $4^{\text {th }}$ month, the border of the intact cartilage is clearly visible, but by the $6^{\text {th }}$ month it becomes indistinguishable. The underlying bone tissue underwent significant resorption in the immediate vicinity of the defect. However, there were no signs of osteodystrophy in the surrounding spongy substance (Fig. 4).

Coarse fibrous connective tissue appeared at the site of the removed cartilage and resorbed bone tissue. The formation and maturation of the connective tissue was first noted at the first animal withdrawal timepoint, and by the $6^{\text {th }}$ month its volume decreased (see Table). In parallel, active reparative processes of bone tissue - neoosteogenesis - were evident along the edges of the bone defect. Initially, the defect had a bulbous shape, but later it turned cylindrical and by the $6^{\text {th }}$ month became wedge-shaped. From the $2^{\text {nd }}$ to the $4^{\text {th }}$ months, the defect was mainly filled with coarse fibrous tissue, and by the 6th month it was almost completely covered with bone tissue. Chondrocytes formed actively (neochronogenesis) not only at the edge of the intact cartilage but also in the center of the defect (see Fig. 4). In the center of the defect there was a deep slit cavity extending relatively deep into the spongy substance.
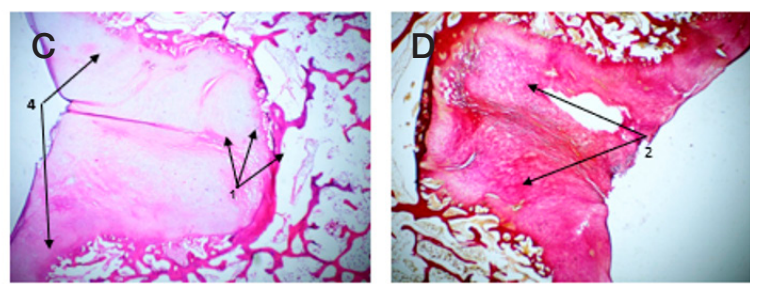

3 months
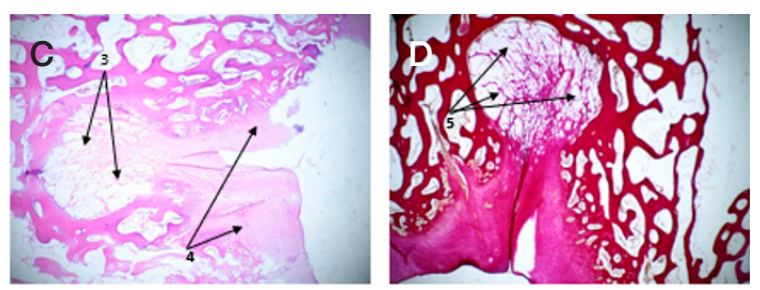

6 months

Fig. 5. Microscopic examination of defect No. 2 after implantation of the Chondro-Gide membrane, stained with hematoxylin and eosin, $\times 40$ (A); Van Gieson's stain, $\times 40$ (B). 1 - fibrin; 2 - coarse fibrous connective tissue; 3 - emerging bulbous defect, active neoosteogenesis evident along the edges; 4 - neochondrogenesis; 5 - the bed of the bone defect filled with adipocytes 
Table. Dimensional characteristics of the histological structure of the defect's center, various types of treatment

\begin{tabular}{|c|c|c|c|c|c|}
\hline & Group & $\begin{array}{c}2 \text { months } \\
(\mathrm{M} \pm m)\end{array}$ & $\begin{array}{c}3 \text { months } \\
(\mathrm{M} \pm m)\end{array}$ & $\begin{array}{c}4 \text { months } \\
(\mathrm{M} \pm m)\end{array}$ & $\begin{array}{c}6 \text { months } \\
(\mathrm{M} \pm m)\end{array}$ \\
\hline \multirow{3}{*}{ Intact cartilage thickness, $\mu \mathrm{m}$} & Control & $734,0 \pm 16,12$ & $2247,5 \pm 36,94$ & $2359,8 \pm 38,79$ & $842,10 \pm 21,23$ \\
\hline & Chondro-Gide & $1118,5 \pm 21,81$ & $1230,4 \pm 23,99$ & $1291,9 \pm 25,19$ & $838,67 \pm 19,12$ \\
\hline & Ortokeep & $1519,0 \pm 38,42$ & $1670,5 \pm 42,26$ & $1341,3 \pm 25,08$ & $886,35 \pm 10,44$ \\
\hline \multirow{3}{*}{$\begin{array}{l}\text { Cartilage thickness at the treatment } \\
\text { site's center, } \mu \mathrm{m}\end{array}$} & Control & 0 & 0 & 0 & 0 \\
\hline & Chondro-Gide & 0 & $503,9 \pm 22,74$ & $571,4 \pm 29,96$ & $252,68 \pm 12,19$ \\
\hline & Ortokeep & 0 & $534,0 \pm 36,42$ & $657,1 \pm 34,46$ & $335,94 \pm 13,47$ \\
\hline \multirow{3}{*}{$\begin{array}{l}\text { Connective tissue thickness at the site of } \\
\text { implantation, } \mu \mathrm{m}\end{array}$} & Control & $1635,2 \pm 187,33$ & $1152,2 \pm 124,80$ & $1094,6 \pm 118,56$ & $2406,98 \pm 178,05$ \\
\hline & Chondro-Gide & $1648,2 \pm 137,34$ & $1615,2 \pm 134,60$ & $1534,5 \pm 127,87$ & $900,58 \pm 72,43$ \\
\hline & Ortokeep & $2072,0 \pm 339,89$ & $1968,6 \pm 322,90$ & $2905,7 \pm 204,92$ & $1688,66 \pm 71,60$ \\
\hline \multirow{3}{*}{ Cortical plate thickness in the intact area, $\mu \mathrm{m}$} & Control & $162,9 \pm 6,33$ & $121,9 \pm 7,27$ & $134,0 \pm 8,00$ & $53,22 \pm 4,08$ \\
\hline & Chondro-Gide & $162,2 \pm 8,37$ & $181,6 \pm 9,38$ & $199,8 \pm 10,32$ & $102,18 \pm 6,60$ \\
\hline & Ortokeep & $181,0 \pm 9,92$ & $198,6 \pm 10,91$ & $226,0 \pm 12,03$ & $84,53 \pm 5,15$ \\
\hline \multirow{3}{*}{ Cortical plate thickness at the treatment site, $\mu \mathrm{m}$} & Control & $121,6 \pm 7,73$ & $96,8 \pm 5,53$ & $106,5 \pm 6,08$ & $147,54 \pm 18,67$ \\
\hline & Chondro-Gide & $140,4 \pm 13,67$ & $157,3 \pm 15,31$ & $173,0 \pm 16,84$ & $184,76 \pm 5,48$ \\
\hline & Ortokeep & $149,0 \pm 11,01$ & $164,4 \pm 12,11$ & $163,9 \pm 14,81$ & $142,66 \pm 19,93$ \\
\hline \multirow{3}{*}{ Bone tissue volume, \% } & Control & $18,9 \pm 0,63$ & $18,5 \pm 0,62$ & $20,4 \pm 0,68$ & $10,42 \pm 0,67$ \\
\hline & Chondro-Gide & $16,3 \pm 028$ & $19,2 \pm 0,33$ & $21,1 \pm 0,36$ & $17,41 \pm 0,36$ \\
\hline & Ortokeep & $27,0 \pm 0,67$ & $29,8 \pm 0,73$ & $27,1 \pm 0,57$ & $30,23 \pm 0,34$ \\
\hline \multirow{3}{*}{ Cartilage tissue volume, \% } & Control & $15,4 \pm 0,51$ & $22,4 \pm 0,74$ & $24,6 \pm 0,82$ & $10,64 \pm 0,38$ \\
\hline & Chondro-Gide & $23,1 \pm 0,29$ & $25,8 \pm 0,33$ & $28,4 \pm 0,36$ & $15,04 \pm 0,72$ \\
\hline & Ortokeep & $27,0 \pm 0,57$ & $29,4 \pm 0,63$ & $32,1 \pm 1,88$ & $19,99 \pm 0,43$ \\
\hline \multirow{3}{*}{ Connective tissue volume, \% } & Control & $53,3 \pm 0,70$ & $52,3 \pm 0,69$ & $44,4 \pm 0,58$ & $13,31 \pm 1,04$ \\
\hline & Chondro-Gide & $53,2 \pm 0,50$ & $40,4 \pm 0,48$ & $34,4 \pm 0,41$ & $17,03 \pm 0,56$ \\
\hline & Ortokeep & $43,0 \pm 0,47$ & $33,7 \pm 0,47$ & $31,2 \pm 0,46$ & $18,19 \pm 0,53$ \\
\hline \multirow{3}{*}{ Volume of blood vessels, $\%$} & Control & $5,8 \pm 0,16$ & $7,1 \pm 0,20$ & $6,8 \pm 0,19$ & $8,39 \pm 0,42$ \\
\hline & Chondro-Gide & $7,5 \pm 0,45$ & $8,9 \pm 053$ & $8,4 \pm 0,50$ & $11,91 \pm 0,42$ \\
\hline & Ortokeep & $9,0 \pm 0,36$ & $9,5 \pm 0,40$ & $10,7 \pm 0,83$ & $12,79 \pm 0,65$ \\
\hline
\end{tabular}

Examination of the histological slides of samples with the Chondro-Gide membrane revealed no inflammatory process and leukocyte infiltration at all animal withdrawal timepoints. The border of the destroyed cartilage was indistinct. In the center of the defect area there appeared a slit cavity, and the underlying bone tissue underwent resorption (the depth of resorption was less than registered in the control group). Coarse fibrous connective tissue appeared where the resorbed bone tissue was, with bone tissue tending to form along the edge of the defect, same as the multiple islets of chondrocytes in the thickness of the defect. The defect had a bulbous shape; neochondrocytes formed more actively in the direction from the periphery to the center. There were separate slit cavities in the thickness of the coarse fibrous connective tissue. A rather pronounced layer of fat cells has formed between connective tissue and bone tissue at the bed of the defect. The neoangiogenesis processes were intense. Islets of chondrocytes also formed in the thickness of the connective tissue, but, in contrast to defect № 1, they were found closer to the developing callus (Fig. 5).

Analyzing results of the measurements, we noted that in the control group a new cartilage has never fully formed in the in the center of the operation area (Table). The same is true for groups 1 and 2 at the $2^{\text {nd }}$ month of the study, but starting from the $3^{\text {rd }}$ month, the cartilage became detectable and its thickness was increasing significantly $(p<0.05)$ up to the $4^{\text {th }}$ month, with the gain being $18.7 \%(657.1 \pm 34.46 \mu \mathrm{m})$ in the $1^{\text {st }}$ group and $12.8 \%(571.4 \pm 29.96 \mu \mathrm{m})$ in the second group. However, by the $6^{\text {th }}$ month the thickness decreased significantly $(p<0.05)$, by $51.1 \%$ in the 1 st group and by by $44.2 \%$ in the $2^{\text {nd }}$ group $(335.94 \pm 13.47 \mu \mathrm{m}$ and $252.68 \pm$ $12.19 \mu \mathrm{m}$, respectively), which is most likely associated with the process of "organization" of the cartilaginous tissue. This fact underscores the efficacy of membranes.

The thickness of the connective tissue in the control group increased by $32.1 \%(p<0.05)$ by the 6 th month, while in groups 1 and 2 it decreased $(p<0.05)$ by $18.5 \%(1688.66 \pm 71.60 \mu \mathrm{m})$ and $46.4 \%$ (900.58 $\pm 72.43 \mu \mathrm{m})$, respectively. Shrinking connective tissue indicates reparative processes in the area of operation. In group 2, the thickness of the connective tissue was decreasing rapidly because it was replaced with adipose tissue, which somewhat worsens the ultimate repair with bone tissue.

By the $6^{\text {th }}$ month, the thickness of the cortical plate at the surgery site increased by $(p<0.05)$ by 17.6 and $24.0 \%$ in the control and $2^{\text {nd }}$ groups, respectively, while in the $1^{\text {st }}$ group it was decreasing from month 2 to month $6(p>0.05)$ by $4.3 \%$. For the most part, the cortical plate gained in thickness due to the formation of the new tissue (osteoid). Subsequently, that tissue matured, with maturation starting earlier in group 1, which suggests the surgery site in that group offered more favorable conditions therefor. 
The above changes at the surgery sites zones are confirmed by the component percentage ratio data shown in the Table.

It is also worth noting the processes of neoangiogenesis. The area of blood vessels increased significantly $(p<0.05)$ in all groups, But the fastest growth thereof was registered in the $1^{\text {st }}$ group (up to $12.79 \pm 0.65 \%$ ), which indicates the trophism of the surgery site tissues was best there. In group 2, the area of connective tissue increased to $11.91 \pm 0.42 \%$.

\section{DISCUSSION}

The demonstrated poor efficacy of bone tunneling applied without additions to the treatment casts doubt on the feasibility of performing such operations in clinical practice, which is confirmed in studies by other authors [1]. The high efficacy of collagen membranes in regeneration of cartilage tissue that we have witnessed in this study accords with the results reported by other researchers [1-4]. Unfortunately, it is not possible to correctly compare the digital values, since the works cited employed different biomodels. It also seems important to study the data describing more long-term results and set up a study to investigate the efficacy of membranes of different compositions.

\section{References}

1. Garkavi AV, Blokov MYu. Artroskopicheskaja hondroplastika lokal'nyh hrjashhevyh defektov kolennogo sustava s ispol'zovaniem kollagenovoj membrany Chondro-Gide. Kafedra travmatologii ortopedii. 2015; 15 (3); 4-7. Russian.

2. Gao L, Orth P, Cucchiarini M, Madry H. Autologous MatrixInduced Chondrogenesis: A Systematic Review of the Clinical Evidence. Am J Sports Med. 2019; 47 (1): 222-31.

3. Benthien JP, Behrens P. Autologous Matrix-Induced Chondrogenesis (AMIC) combining Microfracturing and a Collagen I/III Matrix for Articular Cartilage Resurfacing. Cartilage. 2010; 1 (1): 65-8.

4. Girolamo L, Schönhuber HI, Vigano M, et al. Autologous MatrixInduced Chondrogenesis (AMIC) and AMIC Enhanced by Autologous Concentrated Bone Marrow Aspirate (BMAC) Allow for Stable Clinical and Functional Improvements at up to 9 Years Follow-Up: Results from a Randomized Controlled Study. Journal

\section{Литература}

1. Гаркави А. В., Блоков М. Ю. Артроскопическая хондропластика локальных хрящевых дефектов коленного сустава с использованием коллагеновой мембраны ChondroGide. Кафедра травматологии и ортопедии. 2015; 15 (3); 4-7.

2. Gao L, Orth P, Cucchiarini M, Madry H. Autologous MatrixInduced Chondrogenesis: A Systematic Review of the Clinical Evidence. Am J Sports Med. 2019; 47 (1): 222-31.

3. Benthien JP, Behrens P. Autologous Matrix-Induced Chondrogenesis (AMIC) combining Microfracturing and a Collagen I/III Matrix for Articular Cartilage Resurfacing. Cartilage. 2010; 1 (1): 65-8.

4. Girolamo L, Schönhuber HI, Vigano M, et al. Autologous MatrixInduced Chondrogenesis (AMIC) and AMIC Enhanced by Autologous Concentrated Bone Marrow Aspirate (BMAC) Allow for Stable Clinical and Functional Improvements at up to 9 Years Follow-Up: Results from a Randomized Controlled Study. Journal

\section{CONCLUSIONS}

Both of the tested materials (Ortokeep and Chondro-Gide collagen membranes) showed excellent results in regeneration of a full-thickness cartilage defect. Almost identical macroscopic and microscopic results were registered in both experimental groups. However, a more detailed analysis of the histological examination data revealed the following features: 1) in both groups, the area of collagen membrane implantation was a patch of fibrous connective tissue with inclusions of chondrocytes; 2) at the defect sites, collagen membranes created better conditions for reparative processes, which is confirmed by the shortest terms of closure of the defect with the body's connective tissue; 3) maturation of the connective tissue took less time; 4) in the zone of membrane implantation, chondrogenesis was "scattered", with islets of hyaline cartilage appearing in the formed coarse fibrous connective tissue, such islets detectable by the $3^{\text {rd }}$ month of the experiment and initially distant from each other but tending to merge at later withdrawal timepoints; neochondrogenesis was evident not only at the healthy tissue border but also in the thickness of the connective tissue callus; 5) the figures reflecting bone and cartilage tissue volumes prove the efficacy of collagen membranes. of Clinical Medicine. 2019; 8 (3): 392-405.

5. Kon E, Filardo G, Brittberg M, Busacca M, et al. Multilayer biomaterial for osteochondral regeneration shows superiority vs microfractures for the treatment of osteochondral lesions in a multicentre randomized trial at 2 years. Knee Surgery Sports Traumatology Arthroscopy. 2018; 26 (2): 2704-15.

6. Egiazaryan KA, Lazishvili GD, Hramenkova IV, Shpak MA, Badriev DA. Knee osteochondritis desiccans: surgery algorithm. Bulletin of RSMU. 2018; 2: 73-80. Russian.

7. Lazishvili GD, Egiazarjan KA, Ratev AP, Gordienko DI, But-Gusaim AB, Chulovskaja IG, i dr. Gibridnaja kostnohrjashhevaja transplantacija - innovacionnaja tehnologija dlja hirurgicheskogo lechenija obshirnyh kostno-hrjashhevyh defektov kolennogo sustava. Hirurgicheskaja praktika. 2019; 40 (4): 10-18. Russian. of Clinical Medicine. 2019; 8 (3): 392-405

5. Kon E, Filardo G, Brittberg M, Busacca M, et al. Multilayer biomaterial for osteochondral regeneration shows superiority vs microfractures for the treatment of osteochondral lesions in a multicentre randomized trial at 2 years. Knee Surgery Sports Traumatology Arthroscopy. 2018; 26 (2): 2704-15.

6. Егиазарян К. А., Лазишвили Г. Д., Храменкова И. В., Шпак М. А., Бадриев Д. А. Алгоритм хирургического лечения больных с рассекающим остеохондритом коленного сустава. Вестник РГМУ. 2018; 2: 77-83.

7. Лазишвили Г. Д., Егиазарян К. А., Ратьев А. П., Гордиенко Д. И., Бут-Гусаим А. Б., Чуловская И. Г., и др. Гибридная костнохрящевая трансплантация - инновационная технология для хирургического лечения обширных костно-хрящевых десектов коленного сустава. Хирургическая практика. 2019; 40 (4): 10-18. 